\title{
Buying Decision: The Links Between Online Media and Face To Face Interaction
}

\author{
Selwendri' ${ }^{1}$ Rumyeni ${ }^{2}$ \\ Dept Business Administration Science, Faculty of Social and Politic, Sumatera Utara University, Medan, Indonesia ${ }^{1}$ \\ Dept of Communication Science, Faculty of Social and Politic, Riau University, Pekanbaru, Indonesia ${ }^{2}$ \\ selwendri.usu@gmail.com ${ }^{1}$,rumyeni.arum@gmail.com ${ }^{2}$
}

\begin{abstract}
The purchase decision of consumers on a product can be influenced by various things as advertising, media and environmental factors. From the perspective of media, the purchase decision of people did not only came from a single media only.. On the other hand, a tendency to reduce the risk in the buying will encourage consumers to build a better understanding of products So, based on the media richness theory, this study seeks to identify the relationship between online media and media face-to-face on the strengthening of understanding consumers of products finally affect decision their purchases .This research focus on social media, google searching machine, friends or family and store choice as a media that is attributed to consumers to explain the uncertainty concerning price, function, quality, brand, warranty and design of cellular phone product.The research was done in students of the faculty of social science and politics university riau pekanbaru. 96 questionnaire have been distributed in this study in the field, data analyzed use spss version 17 . The results indicate online media are a source of information first consumers of products but not in terms of decisionmaking. While, friends or family and stores choice is a source of information appendages for those to strengthen understanding of products before make a purchase decision. In conclusion, a combination between friends and stores choice is a media that affects the process of purchase decision making by consumers cellular phone products.
\end{abstract}

Keywords: Buying decision, The Link Between Media, Media Richness Teory.

\section{INTRODUCTION}

In the purchase decision-making process, usually customers would refers to various media that is to strengthen beliefs and they can well a product.These forms of media could be the print, electronic, both new media and individuals. The emergence of various new media currently has been meet the individual needs in searching process of information because can be described simple, easy, and flexible. According to Md Yahya ( 2013 ), current public tended to the media print, and electronic media new media compared with communication in face to face.The problem is, whether this media truly capable to produce a communication that is effective in all aspects ? Especially when he relating to the purchase decision-making of consumers.

The emergence of new media like facebook, instagram, twitter and others has change the individual complexion communication.The application owned by any new media made a communication is more simple and interesting.
Furthermore, the various communication were allow it to be accessed anytime and anywhere.Based on survey of the internet service providers indonesia (APJII) that 132,7 Million people in indonesia, uses the internet which more than half of Indonesian citizen 256,2 Million (APJII, 2016).

The tendencies of society on the use of online media to develop the concept of communication by word of mouth (WOM) traditionally to WOM communication more global for example through electronic media (eWOM) .The ability of eWOM in achieving consumers breakthrough the time limit and the distance also has attracted many entrepreneur to made online media as a platform to market destination and to create good relations with consumers.It seen as an important beginning to influence the purchase attitudes and behavior of consumers (Bataineh, 2015).

However, information from online media often associated with credibility issues.The 
individual trust to a information much influenced by validity of source convey the information (Bataineh, 2015).Consumers being conscientious usually will not dependent on information from just one media especially when it related with the purchase decision. (Maity \&Dass, 2014). According to the media richness theory, online media having a high aptitude in providing information to consumers through the various language, but on the other hand he limited from a spontaneous communication, response immediately and focus on consumerspersonal( Daft \&Lengel, 1986; Maity \&Dsass, 2014 ).

Next, a series of online media are categorized as a medium that has fortune characteristics at thesimple stage (Maity \&Dass, 2014).On the contrary, face-to-face communication is regarded as the efficient media and has characteristics of high riches because of its ability to responses immediately, supported a number of cue, using language that natural and focus on personal individual (Daft \& Lengel, 1986; Simon \& Peppas, 2004; Liu, Rau \&Wendler, 2014 J.In addition, media at a high richeshierarchy also said high influence in increasing phase trust and support information exchange between individual (Rockmann \&Northcraft, 2008; Cho, Philips, Hageman \&Patten, 2009; Liu , Rau \&Wendler, 2014 ).Literature study shows, form limitasi about how each media from a different riches hierarchy attributable each other in producing effective communication on an individual. So, based on the characteristics of different riches from various media, this study seeks to identify is the understanding of consumers of a product supported by informations connected through media from a different riches hierarchy which eventually will affect their purchases decision.

The results of previous research conducted by Mohamad, et al (1999) titled the purchase decisions: Interwoven between print, online media, and face-to-face media shows that brochure and social media become the first reference for consumers in search of information about computer products, but face-to-face media such friends and store selection is a source of information that has a greater influence in determining conumer purchasing decisions.

\section{RESEARCH METHODS}

The study is done through the quantitative approach based on to the method cross-sectional review as a design research. Analysis unit of the study is individual namely consumers who buy products mobile phone.Based on purposive sampling technique, study focus on students of Social and Politics Faculty at Riau University who purchase products cell phone, smartphone, and tablet in pekanbaru .Respondents in this research is 96 people

The development of research instruments is based on to the concept of media riches put forward by media richness theory. Emphasis is against consumers uncertainty factors and the balance between duty communication with media translated through the concept of the links between media.Analysis descriptive statistics program is done by SPSS statistics 17.0 to present demographic respondents information, product purchased, consideration factors in products purchase, consumer information media, the relationship between media in strengthening consumers understanding against products in making the purchase decision of respondents. Data obtained were presented in the form of frequency and percentage. For the problems of consumers uncertaintyfactors, consumers media information and interweaving the media, value frequency and percentage will determine the number of the highest scores.

\section{RESULTS AND DISCUSSION}

The results of research is the presentation of data result that researchers has been obtained after conducting research. The research is field research, where to get something out of it, researchers used questioner as a tool to collect the primary data given directly to respondents as many as 96 people students of the Faculty of Social and Politics Science University of Riau .After the data is collected, Researchers conducted classifications based on respondents can be described and classify the data based on the problems that have been explained earlier and next researchers conducted data processing by doing tabulation and calculate its mean value of any the answer frequency that has been granted by respondents. 


\section{Respondents Identity}

In this research identity respondents divided on the basis of sex, age, and semester.Identity of respondents can provide a picture in general about respondents demographic in this research.In detail identity respondents to research can be seen in the following table 1 :

Table 1

Respondents Identity

\begin{tabular}{|c|c|c|}
\hline $\begin{array}{c}\text { Respondents } \\
\text { Profile }\end{array}$ & Frequency & Percentage \\
\hline $\begin{array}{c}\text { Gender } \\
\text { Male }\end{array}$ & 41 & 42,7 \\
Female & 55 & 57,3 \\
\hline Age (Year) & & \\
18 & 1 & 1 \\
19 & 6 & 6,3 \\
20 & 45 & 46,8 \\
21 & 22 & 22,9 \\
22 & 14 & 14,6 \\
23 & 8 & 8,4 \\
\hline Semester & & \\
3 & 6 & 6,3 \\
5 & 60 & 62,5 \\
7 & 15 & 15,6 \\
9 & 12 & 12,5 \\
11 & 3 & 3,1 \\
\hline
\end{tabular}

Source : Processed researchers data, 2016

Based on table 1 look that the sex respondents in this research is dominated by female although the gap is not too significant, with 55 respondents women or 57.3 percent, and the remaining 41 people or 42.7 percent is a male .While age respondents in this research is range of 18 to 23 years. Most Respondents is 20-yearold by the number of 45 respondents or 46,8 percent and the majority are in semester $5^{\text {th }}$ with 60 respondents or 62.5 percent.

\section{Product Purchased by Respondents}

Product on this research focused on the mobile phone which includes cell phone, smartphone, and tablet. Table 2 describes details the kind of product mobile phone ever bought by respondents.
Table 2

Kind of Product Respondents Ever Purchased

\begin{tabular}{|l|c|c|}
\hline $\begin{array}{l}\text { Kind of } \\
\text { product } \\
\text { purchased }\end{array}$ & Frequency & Percentage \\
\hline Handphone & 5 & 5,2 \\
Smartphone & 87 & 90,6 \\
Tablet & 4 & 4,2 \\
\hline Total & $\mathbf{9 6}$ & $\mathbf{1 0 0}$ \\
\hline
\end{tabular}

Source : Processed researchers data, 2016

In table 2 it can be seen that the kind of product that ever bought by the majority is smartphone with 87 people or 90,6 percent, meanwhile the rest for the kind of product cell phones and tablet each only 5 person or 5.2 percent who buys cell phones and four people or 4.2 percent of who buys tablet. This indicates that at this time,the most favorite kind of mobile phone by students is a smartphone.With various feature and ease owned by smartphone, make students could be met all needs in communication, interact, and various needs as triangulates the source reference by lecture, makes an assignment, and for the implementation of lecture virtually which has been applied in some majors in Faculty of Social and Politic at Riau University.

Next there are various alternative brand of mobile phone available in the market.Table 3 below gives descriptions of brand device mobile phone ever bought by respondents in this research

Table 3

Product Brand Purchase by Respondents

\begin{tabular}{|l|c|c|}
\hline $\begin{array}{c}\text { Product } \\
\text { Brand }\end{array}$ & Frequency & Percentage \\
\hline Samsung & 32 & 33,3 \\
Apple & 11 & 11,5 \\
Oppo & 6 & 6,3 \\
Asus & 13 & 13,5 \\
Xiaomi & 10 & 10,4 \\
Sony & 4 & 4,2 \\
Vivo & 4 & 4,2 \\
Lainnya & 16 & 16,6 \\
\hline Total & $\mathbf{9 6}$ & $\mathbf{1 0 0}$ \\
\hline
\end{tabular}

Source : Processed researchers data, 2016 
Among various brands, Samsung is majority brand of mobile phone bought by respondents with 32 respondent or 33.3 percent.This proved that although mobile phone products competition in the market so fierce by the existence of various new brand, but Samsung was able to maintain its position as market leader.Different innovations born from this product with various virtue it does possess make Samsung still capable of being positioned at the top.While brand Apple, Asus, Xiaomi, Oppo, Sony, Vivo, and other was chosen by respondents did not up to 15 percent for each brand.

\section{Media Reference In Seeking Information Mobile Phone Products}

Before making a decision to do purchases in online stores, usually the consumer will be looking for information about the product and brand that they are going to buy.Sources of information listed usually derived from social media, google searching machine, friends or family, and a store that sells mobile phone device.In table 4 can be seen various media reference used by respondents in search of information about mobile phone products

Table 4

Respondent Reference Media

\begin{tabular}{|l|c|c|}
\hline $\begin{array}{c}\text { Reference } \\
\text { Media }\end{array}$ & Frequency & Percentage \\
\hline Social Media & 15 & 15,6 \\
Google Search & 55 & 57,3 \\
Engine & 20 & 20,8 \\
Friend/Family & 6 & 6,3 \\
Store & & \\
\hline Total & $\mathbf{9 6}$ & $\mathbf{1 0 0}$ \\
\hline
\end{tabular}

Source : Processed researchers data, 2016

Respondents in this research the majority seek for information about products mobile phone that will they buy through google searching machine with 55 respondents or 57.3 percent.A source of information to the two most many chosen by respondents as a reference is friends or family, with 20 people respondents or 20.8 percent.It 6 people respondents or 6.3 percent said looking for information about products mobile phone that will they buy from a store.Meanwhile respondents who made social media as a medium reference to getting information is 15 people or 15.6 percent.
The analysis shows that google searching engine become the main reference for the majority of respondents to get info about products.The knowledge and understanding formed were then supported by friends/family, social media, and stores choice.The dominant choice for the customers to google searching machine because ease that is in thismedia.They can access online media everywhere and anytime easily and the cost relatively cheap.Friends and family also are a source of information being the chief that chosen by many respondents as a source of information.This indicates that their tendency to get the information is against media that offers two way communication.In addition to allow feedback immediately, friends or family also be a pleasant close to consumers, accessible and trustworthy. Information from word of mouth was the nearest known by consumers usually having the levels of higher trust than information from other sources like advertising or personal selling done by sales or marketing of product

Social media was known also play role as the main source of information for those. It is considered trusted and should not be indisputably for the power broad in provided information on products to consumers.Meanwhile, media such as other stores choicesstore known to be last media referred by consumers.Is the norm for a consumers to seek for information and building an understanding on products through mediamedia before refer to the one who sells. Reference the customers to chosen store happens when desire to purchase products is high and aims to strengthen our insights has formed through other media before.

\section{Consideration in Purchase Product}

Many reasons into consumers consideration in choosing mobile phone products, such because the price, function,quality, brand, design, and features.In table 5 below can be seen consideration underlying respondents when purchase products mobile phone. 
Table 5

\section{Consideration Among Respondents to Purchase Products Cellular Phone}

\begin{tabular}{|c|c|c|}
\hline $\begin{array}{l}\text { Consideration } \\
\text { buy mobile } \\
\text { phone }\end{array}$ & Frequenty & Percentage \\
\hline Price & 7 & 7,3 \\
Function & 16 & 16,6 \\
Quality & 52 & 54,1 \\
Brand & 5 & 5,2 \\
Design & 1 & 1 \\
Fiture & 15 & 15,6 \\
\hline Total & $\mathbf{9 6}$ & $\mathbf{1 0 0}$ \\
\hline
\end{tabular}

Source : Processed researchers data, 2016

Among various reasons in purchase mobile phone products, the majority of respondents in this research made quality as basis of consideration purchase products.52 respondent or 54,1 percent of respondents said that they purchase products mobile phone because the quality of the products.Next 16 respondents or by 16.6 percent of respondents purchase products on the basis of its function, in addition features products became the reason for 15 respondents or 15.6 percent in purchase products.Only 7 people or 7.3 percent purchase products mobile phone because consideration price, and relatively little respondents who purchase products mobile phone for reasons of brand, with five people or 5.2 percent.

Based on data above it can be seen that quality is the main factors that be basis of consideration for those in purchase products mobile phone. The quality of being good for products mobile phone can look through various attractive features provided by the device. Complete features of course make a mobile phone has a diverse and many benefit gained by consumers. Next, price is also one of the factors that becomes consederation for consumers in deciding to purchase mobile phone products. The price of a product usually in line with the quality being provided. In this research, we can see that only a little respondents who purchase mobile phone products because brands and design factors. This indicates that in this research mobile phone consumers no longer too loyal in a certain brand, they put more attention to other factors such as quality, features, of function, and price of the products in deciding to buy. In addition, design is very little factors used as consideration to buy bearing in mind that the mobile phone in the market today having almost similar design to every brand

\section{The Relationship Between Media: Amplifier Understanding Consumers}

According to the Media Richness Theory (MRT), every media has characteristics of fortune its own in shed light of understanding to consumers.Not all media able to explain the uncertainty to consumers about products through the same method.Table 6 shows how is the understanding of consumers about the products characteristics was strengthened through the links between online media, social media, friends or family, and stores choice.

\section{Table 6}

Resources Respondents Comprehension Booster

\begin{tabular}{|c|c|c|c|c|c|c|c|c|}
\hline \multirow[t]{2}{*}{$\begin{array}{l}\text { Informati } \\
\text { on Source }\end{array}$} & \multicolumn{2}{|c|}{$\begin{array}{l}\text { Social } \\
\text { Media }\end{array}$} & \multicolumn{2}{|c|}{$\begin{array}{l}\text { Google } \\
\text { Search } \\
\text { Engine }\end{array}$} & \multicolumn{2}{|c|}{$\begin{array}{l}\text { Friend/ } \\
\text { Family }\end{array}$} & \multicolumn{2}{|c|}{ Store } \\
\hline & $\mathbf{n}$ & $\%$ & $\mathbf{n}$ & $\%$ & $\mathbf{n}$ & $\%$ & $\mathbf{N}$ & $\%$ \\
\hline Price & 2 & 2,1 & 49 & 51 & 13 & 13,5 & 32 & 33,3 \\
\hline Function & 2 & 2,1 & 75 & 78,1 & 7 & 7,3 & 12 & 12,5 \\
\hline Quality & 3 & 3,1 & 60 & 62,5 & 16 & 16,7 & 17 & 17,7 \\
\hline Brand & 6 & 6,3 & 54 & 56,3 & 22 & 22,9 & 14 & 14,6 \\
\hline Guarantee & 1 & 1 & 7 & 7,3 & 4 & 4,2 & 84 & 87,5 \\
\hline Design & 6 & 6,3 & 59 & 61,5 & 9 & 9,4 & 22 & 22,9 \\
\hline Feature & 4 & 4,2 & 70 & 72,9 & 7 & 7,3 & 15 & 15,6 \\
\hline
\end{tabular}

Source : Processed researchers data, 2016

The analysis shows consumers understanding of the characteristics of products was strengthened through interlacing media differently.formation Pattern of consumers understanding about product price started from an assessment of information from google searching engine. It was strengthened through information from friends or family that has experience in purchase same products.They will also compare the information to the information they gathered from social media and store choice that is parties determine the price of product in the market. Consumers understanding of functions and product quality known formed through social media before it si attributed with the information from friends or family and stores choice.The state of this indicates that consumers belief can increase caused by a sense of trust to 
knowledge and competence of these parties in explain the subject.

In addition, products brand factors to be consumers attention in the purchase decision. It influenced by consumer advocacy for exhibiting the identity and status.The results indicate doubt consumers of brand products many described by google searching engine before he attributed with the information from friends or family and stores choice.In other words, google searching engine is media who that consumers make judgments products through the comparison between brand in the market.The influence of store choice as a medium building the consumers understanding of warranty and product design also be seen rational because understanding of the characteristics is to be formed when consumers communicate instantaneously with the party who sell the products

As a whole, every media have the ability of its own in clarifying consumers uncertainty.Three mainstream media associated with consumers in clarifying the characteristics of products is google searching engine, friends or family, and stores choice. The media Pattern entanglement indicates the influence of google searching engine as a abundance information platform is still relevant in the context of consumers now although it often associated with credibility issues. While media store choice and friend associated with consumers to rate or validating information obtained through google searching engine. Meanwhile, social media is not seen as make a great difference in the relationship between media by consumers.

\section{The Relationship Between Media: Media Richness Criteria}

Each media own a richness and excess each of them in giving information to prospective consumers about a product.Table 7 below shows how the power of each media to give the understanding to potential consumers seen from 4 criteria media richness including feedback, various cue, language and personal focus.

Table 7 shows how the links between social media, google searching engine, friends or family, and stores choice can be determining the criteria of the richness from the feedback, various cue, language and focus personal.The analysis shows google searching engine, friends or family and stores choices are meet the criteria of media richness from the feedback.And, consumers easy to ask questions and gain a feedback quickly on products through interlacing between each of the these three forms of media.

Table 7

The Relationship Between Media in Determining the Media Richness Criteria

\begin{tabular}{|l|l|l|l|l|l|l|l|l|}
\hline \multirow{2}{*}{$\begin{array}{l}\text { Media } \\
\text { Metween }\end{array}$} & \multicolumn{2}{|l|}{$\begin{array}{l}\text { Social } \\
\text { Media }\end{array}$} & $\begin{array}{l}\text { Google } \\
\text { Search } \\
\text { Engine }\end{array}$ & \multicolumn{2}{l|}{$\begin{array}{l}\text { Friend/ } \\
\text { Family }\end{array}$} & \multicolumn{2}{l|}{ Store } \\
\cline { 2 - 10 } & $\mathbf{n}$ & $\mathbf{\%}$ & $\mathbf{n}$ & $\mathbf{\%}$ & $\mathbf{n}$ & $\mathbf{\%}$ & $\mathbf{N}$ & $\mathbf{\%}$ \\
\hline A. Feedback & 10 & 10,4 & $\mathbf{4 1}$ & $\mathbf{4 2 , 7}$ & 26 & 27,1 & 19 & 19,8 \\
\hline $\begin{array}{l}\text { 1.Most Easy to ask } \\
\text { question }\end{array}$ & 7 & 7,3 & $\mathbf{5 1}$ & $\mathbf{5 3 , 1}$ & 13 & 13,5 & 25 & 26 \\
\hline $\begin{array}{l}\text { 2.The fastest } \\
\text { response }\end{array}$ & & & & & & & & \\
\hline B. Various cue & 3,1 & 9 & 9,4 & 33 & 34,4 & $\mathbf{5 1}$ & $\mathbf{5 3 , 1}$ \\
\hline $\begin{array}{l}\text { 1.The most obvious } \\
\text { in conversation and } \\
\text { intonation sound }\end{array}$ & 3 & & & & & & & \\
\hline
\end{tabular}




\begin{tabular}{l}
\hline Table 7 continue.. \\
\begin{tabular}{|l|l|l|l|l|l|l|l|l|}
\hline $\begin{array}{l}\text { 2.The most include } \\
\text { text, picture, audio } \\
\text { and video }\end{array}$ & 14 & 14,6 & $\mathbf{7 4}$ & $\mathbf{7 7 , 1}$ & 1 & 1 & 7 & 7,3 \\
\hline $\begin{array}{l}\text { C. Languange most } \\
\text { natural and } \\
\text { understandable }\end{array}$ & 11 & 11,5 & 20 & 20,8 & $\mathbf{4 0}$ & $\mathbf{4 1 , 7}$ & 25 & 26 \\
\hline $\begin{array}{l}\text { D.Most Focus serve } \\
\text { the needs of } \\
\text { personal } \\
\text { consumers }\end{array}$ & 15 & 15,6 & 12 & 12,5 & 3 & 3,1 & $\mathbf{7 6}$ & $\mathbf{7 9 , 2}$ \\
\hline
\end{tabular}
\end{tabular}

Source : Processed researchers data, 2016

From the various cue, the study shows three floating cue which is body language, conversation and intonation sound, and text elements, picture, audio and video.Analysis shows friends or family and stores the options are media meet the criteria various cue through body language and conversation and intonation sound.While google searching Engine and social media trying to to provide various text elements, picture, audio and video to consumers.From the language criteria, friends or family, shop choice and google searching engine known to be able to shed light of understanding to consumers of products through language natural which is that may be understood by consumers.Last is focus personal criteria.The study show that store choice, has highest percenteg as amedia that give focused to consumer"s need. It is because the ability of store sales person untuk provide information about product from various perpektif

\section{CONCLUSION}

The result of this research supporting tenets that became the Media Richness Theory foundation namely face-to-face communication is the most effective media in the process of communication.Face-to-face communication regarded as media that is at a highest richness hierarchy for its ability to explain uncertainty and vagueness individual in fulfill media richnest criteria that is spontaneous communication or give feedback immediately, using different cue communication, using language that comprehended individuals and give focus on individual purposes (Daft \& Lengel, 1986).

In the context of this study, face-to-face communication, shown by entanglement media friends or family and stores choice known make a important difference to attitudes and the purchase behavior of consumers in the mobile phone.The interests of online media as google searching machine and social media as the main source of information for those is cannot be denied.Power of it broad made it possible for consumers to obtain information on products through exchange information from the the purchase customers around the world.But, the limitation from the credibility, communication spontaneous and focus on consumer needs causing it has little influence of the the consumers purchase decision.Shades of search information by consumers on media relatedness between friends or family and store choice in explain the special characteristics of the product also show that this trend consumers is against the media that is credible high, can be trusted and offers two way communication. The concept of interlacing media put forward in this research give you one new perspective on richnest media.Literature review showing how media are classified in the richnest criteria by comparing the characteristics of richnest that they have been given.In this study, richnest criteria shown by identifying how social media, google searching engine, friends or family, and choice stores can be meet the criteria of richnest in coordinated.

\section{SUGGESTION}

Further research it is suggested that would be able to continue the concept of the relationship between this media by showing media-media other in different contexts.The results of the study can then be compared with the results of this study to show the usage pattern media among individual. 


\section{REFERENCES}

APJII (2016) Internet Survey APJII 2016. http://www.apjii.or.id/survei

Bataineh, A. Q. (2015). The impact of perceived eWOM on purchase intention: The mediating role of corporate image. International Journal of Marketing Studies, 7(1), 126-137.

Cho, C. H., Philips, J. R., Hageman, A. M., \& Patten, D. M. (2009). Media richness, user trust, and perceptions of corporate social responsibility. Accounting, Auditing \& Accountability Journal, 22(6), 933-952.

Daft, R. L., \& Lengel, R. H. (1986). Organization information requirements, media richness and structural design. Management Science, 32(5), 554-571

Liu, J., Rau, P. L. P., \& Wendler, N. (2014). Trust and online information-sharing in close relationships: A cross-cultural perspective. Behaviour \& Information Technology, http://dx.doi.org/10.1080/0144929X.2014 .937458 .

Maity, M., \& Dass, M. (2014). Consumer decisionmaking across modern and traditional channels: E-commerce, m-commerce, instore. Decision Support Systems, 61(1), 3446.

http://doi.org/10.1016/j.dss.2014.01.008.

Mohamad, Noraihan, Mohd Shobi Ishak, \& Sabrina Mohd Rashid (2016). Consumers Purchase Decision:Interlacing Between the Print Media, Online Media, and Face to Face Media. Malaysian journal of Communication, Vol. 32 (1) 313 - 334

Rockmann, K. W., \& Northcraft, G. B. (2008). To be or not to be trusted: The influence of media richness on defection and deception. Organizational Behavior and Human Decision Processes, 107, 106-122.

Simon, S. J., \& Peppas, S. C. (2004). An examination of media richness theory in product web site design: An empirical study. Info, 6(4), 270-281. 